but of which nature knows nothing. Are we, then, to conclude that the clinical distinction of benign and malign is to fade from our minds as the baseless fabric of a dream? Shade of Hunter forbid! Does evolution, which indicates the links which bind the mammal to the ascidian and the amoba, cause us to confound their substance? On the contrary, while it enables us to connect them in thought, it assists us in dividing the persons. So must philosophic pathology ever succour rather than impede the clinical student and bedside practitioner.

If, then, we believe that in her wildest vagaries of pathological neoplasm nature makes no jumps; if we recognise a transition between the simple and the specific, the innocent and the malign, chronic inflammation and cancerous infiltration, sarcoma and carcinoma,-in what, then, does cancer consist? In generation, in inflammation, in repair, in carcinomata and sarcomata, the individual factor is morphologically apparently identical; what differences there may be are latent, not expressed. In inflammation, repair, and in malignant growths, then, there is a reversion to embryonal cell type. In the two former processes there is either organisation of embryonal cells into tissue or liquefaction into pus. In the neoplasms, on the other hand, there is an indisposition of the component cells either to differentiate into tissue or to suppurate. They lack the influence which makes for organisation; their instincts are of the lowest-are amceboid, in fact. They possess the fecundity of cells unfitted for "colonial" life, and share their vagabond propensities. Herein lie the factors of malignancy, the causes alike of the rapid growth and the infectivity of cancer. It may also be, as Dr. Creighton with acumen and felicity has put it, that these cells possess a veritable "seminal" influence; that is, by their contact they cause other cells to generate, and make the offspring like themselves; witness a sarcoma of the ciliary body infecting the very lens substance itself. The recent asserted discovery in cancer cells of nuclear structure akin to such as is only found in spermatoblasts may possibly afford a morphological peg on which this theory may be suspended. If it be inquired whence this influence is which makes for malignancy, and what determines its initiation, it can only be replied that we are "the heirs of all the ages" of the lowly amoba no less than of our parents. That as we believe with von Baer that the history of the individual repeats the history of the race, so we carry within us (happily not all in the same deoree) the idiosyncrasies which pertained to the life history of our earliest progenitors. That, while in the processes of repair and of organising inflammation we see a survival of tendencies inherited from a later generation, a generation which had acquired colonial habits and a lower grade of fecundity, and which we regard as beneficent, in the life history and tendencies of the cancer cell we see occasional persistence of (Cohnheim), or reversions to, that still earlier type of a structureless cell, inapt at specialisation, indisposed to colonial collaboration, and multiplying by fission with that terrific rapidity characteristic of the lowliest of living things. I am, Sirs, yours faithfully,

W. J. Collins, M.S., D.P.H. Lond.

Junior Athenæum Club, Piccadilly, W., Aug. 18th, 1888.

TENOTOMY IN CLUB-FOOT.

To the Editors of THE LANCET.

SIRs,--In your report of the proceedings of the Surgical Section of the Glasgow meeting of the British Medical Association (THE LANCET, Aug. 18th, p. 317), I am reported to have said that "tenotomy was never called for." This is so evidently a mistake, that in a less influential journal than THE LANCET the statement, under the circumstances, might be allowed to pass uncorrected. As it is, I shall be obliged if you will permit me to state what I really did say on this point. After describing the anatomy of club-foot, and pointing out the physiological differences between muscles and ligaments as to their extensibility, I went on to say that, as regarded the long slender tendons of the two tibial muscles, "tenotomy as an independent operation" might almost be given up, and that when they required division it was better to divide them together with and at the same time as the ligaments with which they become blended at their insertion. Tenotomy of the Achilles tendon is, $I$ believe, necessary in all cases of equino-varus.

London, Aug. 20th, 1888.

I remain, Sirs, yours faithfully

R. W. PARKER.

\section{COLOUR AND VISION TESTS FOR SEAMEN.} To the Editors of THE LANCET.

SIRS,-In your issue of the 18th inst., an annotation on the very important subject of testing seamen's sight says:"In the mercantile marine, as far as we can learn, the tests for near and distant sight are not insisted on by the controlling board, and a knowledge of those for colour is required of officers only." Permit me to say that in the cunard Steamship Company, in whose service $I$ act as surgeon, there is a printed rule supplied to every surgeon stating that before each voyage he is to test the officers and crew for long and short sight and colour-blindness. He is also reminded of the same at headquarters. I have on several occasions rejected sailors. All new officers joining the service are examined by an oculist in Liverpool, and again by the ship's surgeon on each voyage. I think it would be wise to establish insurance benefits for officers rejected through deficiency of vision. I may also remark that the present system of four hours on and off duty, with its broken sleep, adopted both in the Royal Navy and the Mercantile Marine, is not a system calculated to ensure the best vision on turning out or generally.

August, 1888. I am, Sirs, yours faithfully,

\section{THE BOWER AND KEATES INDEMNITY FUND. To the Editors of THE LANCET.}

Sirs,-We shall be obliged if you will kindly insert the enclosed letter in your next issue, if possible. Thanking you in anticipation,

We are, Sirs, your obedient servants, BOWER AND KEATES.

East Dulwich-road, S.E., August 22nd, 1888.

"To the Subscribers of the Bouer and Keates Indemnity Fund.

"GENTLEMEN, - After four years' legal delay, we are glad to say our troubles are at an end, and we hasten to take the earliest opportunity afforded us to express to the subscribers of the above fund our sincere and grateful thanks for the very great sympathy and support extended to us by our professional brothers during a period of exceptional trial and anxiety. Amongst so many friends who have given valuable time and advice, it would be almost invidious to make distinctions, but we shall always hold in grateful memory the names of the late Drs. Moxon and Mahomed: the former, from the rery commencement of our trouble, although not personally known to us, was ever ready to cheer and support us with his advice; and the latter, as joint hon. secretary, worked hard in our cause. To Dr. Burnet also our special thanks are due for the kindly and able manner in which he has voluntarily and solely borne the arduous duties of honorary secretary since Dr. Mahomed's death. To the Committee we have already privately expressed our gratitude, but we are glad now to be able to give public expression of our thanks to them for all their kind exertions on our behalf.

"We are, Gentlemen, yours very gratefully,

"BOWER AND KE.1TES,

“Tredegar Villas, East Dulwich-road, S.E."

\section{LIVERPOOL.}

(From our own Correspondent.)

\section{HYDROPHOBIA.}

ANOTHER death has recently occurred from hydrophobia, making the third which has taken place in the ricinity of Liverpool within the last two months. In all three inquests were held, the symptoms were the same, the interral between the infliction of the bite and death was short though variable, and in each case there was at least some evidence of the rabidity of the animal, and it was destroved. Steps will have to be taken, if the disease continues to spread, for controlling the large number of stray dogs which are seen in our streets. That prevention is in this case better than cure must be evident to all who have studied the subject.

\section{POISONING BY CARBOLIC ACID.}

A fatal case of poisoning by carbolic aeid formed the subject of an inquiry before the city coroner on the 18th inst. The deceased was a domestic servant of in- 